\title{
Impact of Competition on the Growth of Pinus Tabulaeformis in Response to Climate on the Loess Plateau of China
}

\section{Rumeng He}

Beijing Forestry University

\section{Xuhu Wang}

Gansu Agricultural University

Tao Liu

Institute of Geographic Sciences and Natural Resources Research

Lijun Guo

Beijing Forestry University

Baitian Wang ( $\nabla$ wbaitian@bjfu.edu.cn )

Beijing Forestry University

Alamgir Khan

Beijing Forestry University

\section{Research Article}

Keywords: competition, drought, dendroecology, P. tabulaeformis, Loess Plateau

Posted Date: June 29th, 2021

DOI: https://doi.org/10.21203/rs.3.rs-619294/v1

License: (c) (1) This work is licensed under a Creative Commons Attribution 4.0 International License.

Read Full License

Version of Record: A version of this preprint was published at Plant Ecology on January 11th, 2022. See the published version at https://doi.org/10.1007/s11258-021-01214-5. 
1

2 Impact of competition on the growth of Pinus tabulaeformis in

3 response to climate on the Loess Plateau of China

4 Rumeng $\mathrm{He}^{1}$ Xuhu Wang ${ }^{2}$ Tao Liu $^{3}$ Lijun Guo ${ }^{1}$ Baitian wang ${ }^{1 *}$ Alamgir Khan ${ }^{1}$

$5 \quad{ }^{1}$ College of Soil and Water Conservation, Beijing Forestry University, Beijing, China, 100083.

$6 \quad{ }^{2}$ College of forestry, Gansu Agricultural University, Lanzhou, China, 730070

$7 \quad{ }^{3}$ Qianyanzhou Ecological Research Station, Key Laboratory of Ecosystem Network Observation and

8 Modeling, Institute of Geographic Sciences and Natural Resources Research, Chinese Academy of

9 Sciences, Beijing, China, 100101,.

10

*Corresponding author.

E-mail addresses and phone numbers :

12 forester@gmail.com (Alamgir Khan) wxh2110@163.com (Xuhu Wang);

liutao180916@163.com (Tao Liu)

18306891469@163.com (Lijun Guo);

wbaitian@bjfu.edu.cn (Baitian Wang); Tell: +86-13910595782

Abstract: With climate change, understanding tree responses to climate is important for predicting trees' growth, and plant competition as a nonnegligible biotic factor plays a key role in such response. 
plantations to climate . In our study, we investigated nine 29-year-old P. tabulaeformis plantation plots (three density gradients). The dendroecological method was used to analyze the impact of competition on trees response to drought and interannual climate variation. Stand density index was used to indicate the intensity of competition. The results showed that competition modified the climate-growth relationship. Competition increased trees' sensitivity to drought but the relationship between competition and sensitivity to drought was nonlinear. The competition effect slightly increased under intense competition conditions. Additionally, competition reduced trees' sensitivity to interannual climate variation. After 1999, the effect of competition was obvious. The sensitivity of small-diameter trees, especially those in middle- and high-density stands, declined. Thus, in the future these trees presumably may exhibit a reduced sensitivity to interannual climate variation and a greater sensitivity to drought.

Keywords: competition; drought; dendroecology; P. tabulaeformis; Loess Plateau

\section{Declarations}

Founding This research was supported by the Research and Demonstration of Difficult Site Vegetation Restoration Technology (2015BAD07B02) and the Research on Typical Fragile Ecological Restoration and Protection (2016YFC0501704).

Conflicts of interest/Competing interests No conflict of interest exists in relation to the submission of this manuscript, which has been approved by all authors for publication.

Availability of data and material The data are provided in the Supplementary Material.

\section{Code availability Not applicable}


41 Authors' contributions: Rumeng He collected the data and wrote most part of the article. Xuhu Wang 42 developed the idea and modified the article. Tao Liu drew Fig.1 and modified the article, and polished 43 the language. Lijun Guo helped to collect and calculate the data. Baitian Wang wrote the abstract of the 44 article. Alamgir Khan modified and edited manuscript.

45

46

47

48

49

50

51

52

53

54

55

56

57 


\title{
Impact of intraspecific competition on the growth of Pinus tabulaeformis
} in response to climate on the Loess Plateau of China

\begin{abstract}
With climate change, understanding tree responses to climate is important for predicting trees' growth, and plant competition as a nonnegligible biotic factor plays a key role in such response.
\end{abstract} However, few studies have investigated how competition affects the response of Pinus tabulaeformis plantations to climate . In our study, we investigated nine 29-year-old P. tabulaeformis plantation plots (three density gradients). The dendroecological method was used to analyze the impact of competition on trees response to drought and interannual climate variation. Stand density index was used to indicate the intensity of competition. The results showed that competition modified the climate-growth relationship. Competition increased trees' sensitivity to drought but the relationship between competition and sensitivity to drought was nonlinear. The competition effect slightly increased under intense competition conditions. Additionally, competition reduced trees' sensitivity to interannual climate variation. After 1999, the effect of competition was obvious. The sensitivity of small-diameter trees, especially those in middle- and high-density stands, declined. Thus, in the future these trees presumably may exhibit a reduced sensitivity to interannual climate variation and a greater sensitivity to drought.

Keywords: competition; drought; dendroecology; P. tabulaeformis; Loess Plateau

\section{Introduction}

With climate warming, the frequency of drought is increasing, which has a great effect on ecosystems. Forests are vegetation types that are highly affected by drought. The response of forests to 
drought is influenced by many factors such as damage by insects (DeLucia et al. 2012), nitrogen deposition (Hannusch et al., 2019), an increase in carbon dioxide concentration, and competition. The attack of insects may reduce trees resistance to drought or may increase the rate of tree mortality (Stephenson et al., 2019). A higher carbon dioxide concentration can increase water use efficiency, thus moderating water stress (Rahman et al., 2019). Competition is also a critical factor influencing tree growth and response to climate. Intense competition may exacerbate resource shortages. In a high-competition environment, serious water stress in drought years will affect the physiological activities of trees (Laurent et al. 2003; McDowell et al., 2011; Archambeau et al. 2020; Schmitt et al. 2020), cause growth decline (Jump et al., 2006), forest dieback (Rubio-Cuadrado et al., 2018; Gessler et al., 2018; Zhao et al., 2018), and even reduce biodiversity (Peng et al., 2011; Ploughe et al., 2019). On the Loess Plateau of China, due to the high stand density there are large areas of dense plantations which are suffering from intense competition. Furthermore, the region might become more arid as the climate warms (Liu et al., 2018), which can further exacerbate plant competition, substantially influencing the sustainability of the local ecosystem. Therefore, understanding the competition effect on the response of the major species to climate is essential for forest management. However, how competition affects trees' response to climate remains debatable.

Previous studies have shown contrasting results for competition effects on tree responses to drought. Some researches showed that competition increases with increasing stand density, which may exert a considerable impact on the performance of trees during arid spells. For example, Gleason et al. (2017) observed that competition exaggerated the water deficit and reduced tree resistance during a drought event. Similarly, Bottero et al. (2017) found that competition caused a growth decline in ponderosa pine and led to its low resilience. In addition, Zhang et al. (2015) concluded that intensive competition 
101

102

may increase the mortality rate of trees with a weak ability to compete for resources. In contrast, Floyd et al. (2009) showed that the effect of competition on tress mortality in severe drought was not evident in Pinus edulis Engelm. stand. In addition, van Gunst et al. (2016) showed that in mid- to upper-elevation forests, mortality reduced in dense forests.

Competition also differs among trees of different sizes, which causes divergent responses to drought. Dominant trees with large diameters have stronger competitive abilities to obtain soil water and nutrients. These trees have a greater potential to tolerate water stress and are less sensitive to arid climates compared with small-diameter trees. Colangelo et al. (2017) showed that trees which dead in drought are smaller than living trees. However, in some cases, large trees demand more water. They receive more solar radiation and have longer hydrologic paths than small trees, which could increase the risk of hydraulic failure (McDowell et al., 2015). Thus they would be more sensitive to drought than small-diameter trees (Lingenfelder and Newbery., 2009; McDowell et al., 2015; Keyser et al., 2016; Zhang et al., 2018).

Additionally, various factors, such as micro-environment (Holtmeier et al., 2005), and age (Skubel et al., 2015), modulate the competition effect on trees' response to drought as the climate warms. All of these factors combining with competition may alter trees responses to drought. For instance, favorable soil conditions can buffer the effect of arid climates (Schönbeck et al., 2020). Favorable soil conditions can also support more trees, forming high stand density compared with harsh soil conditions (Paoli et al., 2007). Water and nutrient demands increase as the stand grows, forming an intense competition environment. Dense forests also consume more nutrients and deteriorate soil conditions, leading to more intense competition (Qiu et al., 2019). This process leads to the effects of competition mixed with 
122

123

soil conditions. Besides, the growth of trees with different ages may vary in response to climate (Wilson et al., 2004; Wang et al., 2009; Cavin et al., 2017; Gillerot et al. 2020; Jiao et al., 2020), which may be related to their different physiologies (Greenwood et al., 2008) and the competition they suffer from at different levels (Cescatti et al., 1998). These two factors would be mixed when analyzing the competition effect on the response of trees of different sizes.

For the competition effect on tree response to interannual climate variation, there are some different views. Some researchers have shown that trees living in a intensive competitive environment would be less sensitive to climate change (Fritts 1976). Ford et al. (2016) showed that as potential evapotranspiration (PET, which indicates the availability of energy for growth) and actual evapotranspiration (AET, which indicates the availability of energy and water for growth) increased, trees living under high competition and low competition displayed divergent growth. Zang et al. (2011) also showed that large-diameter tree growth had closer relationships with climate than that of small-diameter ones. However, Jiang et al. (2012) demonstrated that small-diameter trees, which were more suppressed by their neighbors, were more sensitive to climate. Moreover, Kerhoulas et al. (2011) revealed that the effect of competition on tree responses to climate was significant. Given the above debates above, the effect of competition on tree responses to interannual climate variation requires further exploration.

To deeply understand the effects of competition on tree responses to climate, an experiment was conducted in even-aged Pinus tabulaeformis Carr. plantations that have not been thinned after they were planted. P. tabulaeformis is one of the major planting species in northern China. This species has been widely planted on the Loess Plateau to prevent soil erosion due to its properties, such as drought 
143

144

145

resistance and tolerance to barren soil (Zhou et al., 2007). However, because of the high stand density (initial stand density of $3300 \mathrm{stems} / \mathrm{hm}^{2}$ ), the trees' radial growth was slow, and some individuals are growth decline (Berger et al., 2004). Previous studies have demonstrated an increased drought vulnerability in dense pine plantations at xeric sites (Sánchez-Salguero et al., 2013). Thus, climate warming may also increase risks to these individuals and considerably impact their ecological functions. However, few studies have explored the impacts of competition on the response of P. tabulaeformis plantations to climate in the local areas. The main purposes of this study were to explore how competition affects the response of $P$. tabulaeformis to drought, and interannual climate variation. We hypothesized that: 1) competition increases the sensitivity of $P$. tabulaeformis to drought, and the effect may markedly increase with an increase in competition and that 2) the species sensitivity in response to interannual climate variation may gradually decrease due to increasing competition.

\section{Materials and methods}

\subsection{Study site}

The study site is located in Fangshan County, Luliang city, Shanxi Province, China $\left(111^{\circ} 2^{\prime} 50^{\prime \prime} \mathrm{E}-111^{\circ} 34^{\prime} 30^{\prime \prime} \mathrm{E}, 37^{\circ} 36^{\prime} 58^{\prime \prime} \mathrm{N}-38^{\circ} 18^{\prime} 27^{\prime \prime} \mathrm{N}\right.$, Fig. 1). This area has a temperate continental climate. The average annual temperature is $7.3{ }^{\circ} \mathrm{C}$, and the mean annual precipitation ranges from 440 to $650 \mathrm{~mm}$ (http://www.fangshan.gov.cn/zjfs/zrdl/201807/t20180709_732551.html). Higher precipitation often occurs in summer. Drought events have frequently occurred, especially in 1992 , 1997, 1999-2000, 2005-2006, and 2015 (these years with mean standardized precipitation evapotranspiration index (MSPEI) values less than -0.5 representing a drought years, Fig. 2, Yu et al., 


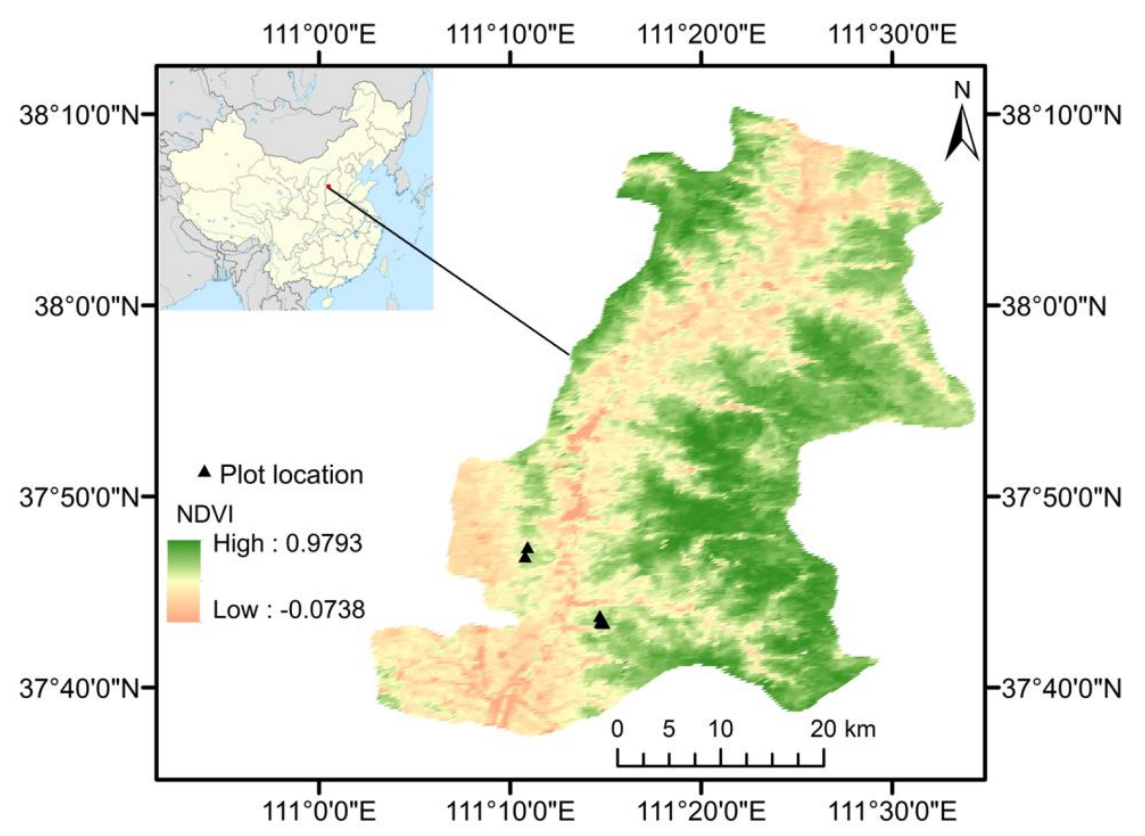

169 Fig. 1 Location of the study site. The background of the main map is the normalized difference vegetation index (NDVI) in 2015. The NDVI data derived from MOD13Q1 was downloaded from the National Oceanic and Atmospheric Administration (NOAA) 

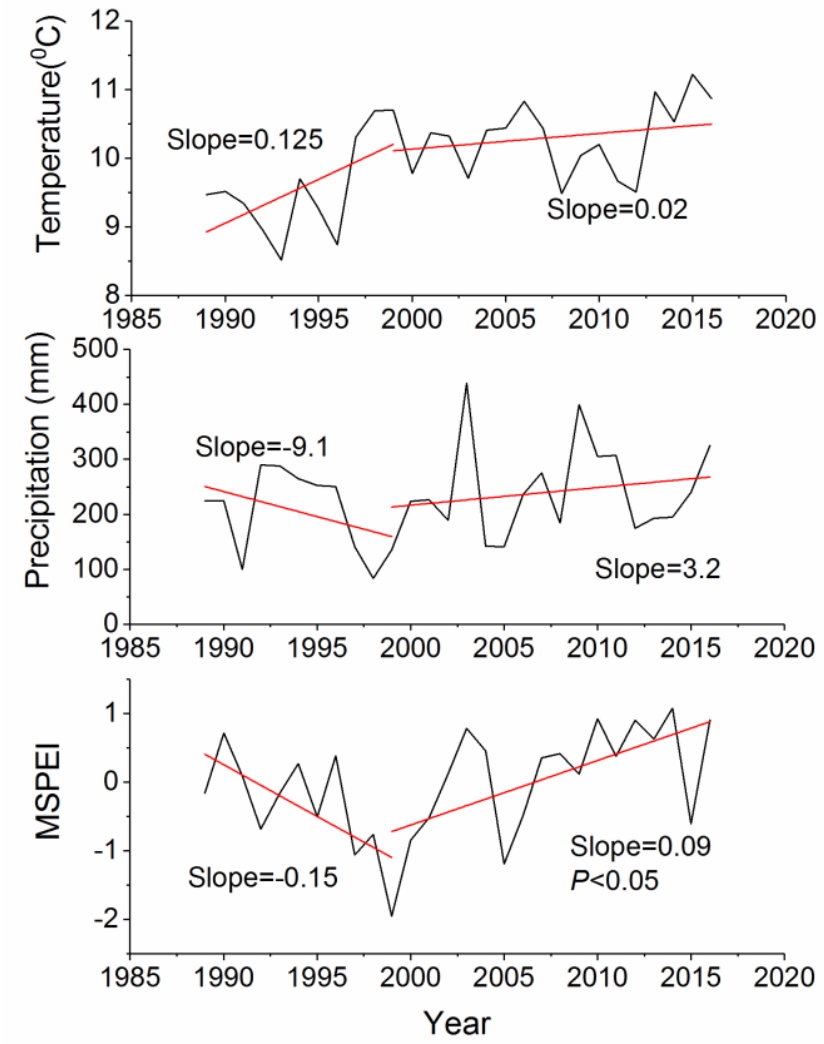

173 Fig. 2 Change in MSPEI. MSPEI is the weighted average of the standardized precipitation 174 evapotranspiration index (SPEI) at the 8-month scale.

\subsection{Data collection}

To analyze the effect of competition on the response of $P$. tabulaeformis to climate, 9 impermanent rectangle plots with similar elevations and aspects were set in even-aged pure $P$. tabulaeformis plantations in May 2018 (Table 1). All of these monoculture plantations were planted in the 1980s and were not thinned after being planted. These trees were approximately 29 years old when the experiment was conducted. We established three density gradients. In each density gradient, the plots were set in stems $/ \mathrm{hm}^{2}$; the average middle density was $2275 \mathrm{stems} / \mathrm{hm}^{2}$; and the average high density was 2989 stems $/ \mathrm{hm}^{2}$. In the plots, we measured the diameter at breast height (DBH) of every tree and recorded its coordinate. Since the diameter range was relatively large and, generally, trees of different sizes in a 
185

186

187

188

189

190

191

192 less than $65 \%$ of the maximum DBH but larger than $6 \mathrm{~cm}$ was defined as the small-diameter class (the

193 DBH of low-density stands ranged $[8,14.2] \mathrm{cm}$, of middle-density stands $[8,13.7] \mathrm{cm}$, and of

194 high-density stands $[8,12.1] \mathrm{cm})$. Two cores per tree were taken from at least 7 trees of every diameter

195 class in each plot. Each core was drilled at breast height, and the direction was parallel to the contour

196 line of the hillside. In total, we obtained 260 cores.

Table 1 Plot information

\begin{tabular}{cccccccccc}
\hline Plot & $\begin{array}{c}\text { Density } \\
(\mathrm{N} / \mathrm{ha})\end{array}$ & $\begin{array}{c}\text { Mean DBH } \\
(\mathrm{cm})\end{array}$ & $\begin{array}{c}\text { DBH range } \\
(\mathrm{cm})\end{array}$ & Longitude & Latitude & $\begin{array}{c}\text { Slope } \\
\text { degree }\end{array}$ & $\begin{array}{c}\text { Aspect of } \\
\text { slope }\end{array}$ & Elevation/m & Plot size \\
\hline 1 & 1125 & 15.5 & $8.2-21.2$ & $111^{\circ} 14^{\prime} 42^{\prime \prime}$ & $37^{\circ} 43^{\prime} 45^{\prime \prime}$ & $20^{\circ}$ & $\mathrm{N} 37^{\circ}$ & 1296 & $20 \times 20 \mathrm{~m}$ \\
2 & 1375 & 14.34 & $6.9-21$ & $111^{\circ} 10^{\prime} 55^{\prime \prime}$ & $37^{\circ} 47^{\prime} 21^{\prime \prime}$ & $14^{\circ}$ & $\mathrm{N} 28^{\circ}$ & 1461 & $20 \times 20 \mathrm{~m}$ \\
3 & 1125 & 15.32 & $6.5-22$ & $111^{\circ} 10^{\prime} 47^{\prime \prime}$ & $37^{\circ} 46^{\prime} 52^{\prime \prime}$ & $15^{\circ}$ & $\mathrm{N} 49^{\circ}$ & 1430 & $20 \times 20 \mathrm{~m}$ \\
4 & 2450 & 12.19 & $5.7-22.1$ & $111^{\circ} 14^{\prime} 54^{\prime \prime}$ & $37^{\circ} 43^{\prime} 24^{\prime \prime}$ & $15^{\circ}$ & $\mathrm{N} 350^{\circ}$ & 1339 & $20 \times 20 \mathrm{~m}$ \\
5 & 2175 & 11.94 & $5.5-20.5$ & $111^{\circ} 14^{\prime} 44^{\prime \prime}$ & $37^{\circ} 43^{\prime} 27^{\prime \prime}$ & $24^{\circ}$ & $\mathrm{N} 22^{\circ}$ & 1291 & $20 \times 20 \mathrm{~m}$ \\
6 & 2200 & 13.12 & $4.5-19.1$ & $111^{\circ} 14^{\prime} 48^{\prime \prime}$ & $37^{\circ} 43^{\prime} 27^{\prime \prime}$ & $22^{\circ}$ & $\mathrm{N} 33^{\circ}$ & 1305 & $20 \times 20 \mathrm{~m}$ \\
7 & 2700 & 11.54 & $5.8-19$ & $111^{\circ} 14^{\prime} 53^{\prime \prime}$ & $37^{\circ} 43^{\prime} 24^{\prime \prime}$ & $15^{\circ}$ & $\mathrm{N} 298^{\circ}$ & 1335 & $20 \times 20 \mathrm{~m}$
\end{tabular}




\subsection{Calculation of the competition index}

To analyze the magnitude of competition, the stand density index (SDI) was used to indicate the competition pressure of a stand (Reineke 1933; Bottero et al., 2017). The SDI was calculated according to

$$
S D I=N\left(D B H_{i} / D B H_{r}\right)^{1.6}
$$

where $\mathrm{N}$ is the number of trees per hectare, $\mathrm{DBH}_{\mathrm{i}}$ is the quadratic mean $\mathrm{DBH}$ of all trees in per hectare, and $\mathrm{DBH}_{\mathrm{r}}$ is the index diameter. In Europe, $25 \mathrm{~cm}$ was used (Pretzsch et al., 2005), while in China, generally the index diameter of $15 \mathrm{~cm}$ or $20 \mathrm{~cm}$ was chosen. Here we used $20 \mathrm{~cm}$, which was used by Yan (2009).

\subsection{Calculation of response indices and the tree ring width index}

Increment cores were dried in a shaded area and then fixed and polished. All of the cores were measured with LINTAB 6 at $0.01 \mathrm{~mm}$ resolution. The COFECHA program was used to assess the cross-dating accuracy (Holmes, 1997).

The dated series were used to calculate the basal area increment (BAI) series by using the "dplr" package in R software (Bunn et al., 2020). Then, the BAI series was used to calculate indices for resistance (Rt), recovery (Rc), and resilience (Rs) (Trujillo-Moya et al., 2018). Rt can be characterized as the ability of trees to withstand a period of water deficit without showing a perceptible decrease in tree ring width $(\mathrm{Rt}<1$ indicates a decline in growth). Rc describes the increase in tree ring width after a 

recovery to predrought growth; otherwise the tree is still experiencing a legacy effect of the drought; are as follows:

$$
R s=p o s t D r / p r e D r
$$

where $r$ is the radius of a tree; $t$ is the year of a tree ring. Dr, preDr and postDr mean BAI in drought, the average BAI of two years before and after a drought, respectively.

To analyze differences in response indexes among trees of different densities and diameters, the tree-ring width chronology (STRWI), the "ModNegExp" method was used to remove tree growth trends. The detrended series was then used to calculate TRWI by using beweight robust mean. In 
addition, the residual chronology (RTRWI) was also established. This process was conducted by using the R package “dplr” (Bunn et al., 2020).

\subsection{Climate data}

Monthly climate data (i.e., precipitation and temperature) from 1989 to 2016 for the Lishi area close to the study site, were downloaded from the National Meteorological Science Data Center of China (http://data.cma.cn/). The data were used to calculate the SPEI. Potential evapotranspiration (PET) was calculated according to the Penman-Monteith equation. This process was conducted by using the R package "SPEI” (Santiago et al., 2017).

The Pearson correlation analysis was used to calculate the correlation between STRWI and RTRWI and SPEI at time scales of 1-12 months. The STRWI has a higher correlation with SPEI when compared with RTRWI, and the correlation is higher at the time scale of 8 months than that at other time scales (Supplementary Information Table S3, and Table S4). We then selected the 8-month SPEI (SPEI8), to calculate the MSPEI, which was calculated by the weighted mean of SPEI8 (Supplementary Information S1). The absolute value of the correlation coefficient between SPEI8 and RTRWI served as the weighting factor.

\subsection{Analysis of trees responding to climate}

To evaluate the effect of competition on trees' response to drought, we developed a linear mixed-effect model for response indices (values were converted to a normal distribution by the square root, high th-root transformations, and reciprocal. The best method was selected by using "powerTransform" function in the "car" package ) using the "nlme" package in R (Pinheiro et al., 
2019). The random effect only considered the plot effect due to the superior results of the residual plot and qq plot of the model considering only plot effect versus those considering the effects of both the plot and the individual (Pinheiro et al., 2000). The model was expressed as follows:

$$
R=\alpha S D I+\beta+\varepsilon
$$

where $\mathrm{R}$ is the response index (Rt, Rc, Rs); SDI is a fixed effect, $\beta$ is a random effect derived from the plot; $\alpha$ and $\varepsilon$ are the coefficient and error, respectively. All statistical analyses were conducted using $\mathrm{R}$ 3.5.1 (R Core Team 2018).

To study changes in trees' response to climate variation, the response ability (relative basal area increment, RBAI) was calculated using the ratio of the BAI to the MSPEI for each density and diameter. Although the traditional method, moving correlation, has been widely used to test the change in the relationship of climate-growth, this method will reduce the length of the correlation series (at the beginning and the ending, the length of the correlation series equal to the window will loss). In our study, the length of the tree ring width was short. Thus, the moving correlation is not suitable for our study. We used the relative basal area increment (RBAI) to analyze the change in the response in the long term.

The RBAI is similar to the meaning of the climate effect on site productivity (Sharma et al., 2018). The response of tree growth (basal area increment, BAI) to climate is related to $\alpha$, as shown by equation six. The larger the $\alpha$, the more sensitive the tree is to climate conditions. The ratio ( $\alpha$, also RBAI ) of the basal area increment to the climate index (MSPEI; in order to make RBAI larger than 0, we add 3 to the series of MSPEI) can indicate trees' response to the interannual climate (equations six). 
where $\alpha$ is the coefficient.

\section{Results}

\subsection{Tree growth response to drought} high density (Fig. 3b). 
$\mathrm{W}=1629, P<0.01$, Fig. 3c). Between diameters, the Rc of the small-diameter trees was larger than that of the large-diameter trees, and the difference was significant at the high density ( $\mathrm{W}=1156, P<0.01$, Fig. 3d), showing that the Rc of the small-diameter trees was more sensitive to the density increase than that of large-diameter trees.

The Rs slightly declined as the density increased. Among densities, the differences were significant (low-middle density $\mathrm{W}=4370, P<0.01$; low-high density $\mathrm{W}=4391, P<0.01$, Fig. $3 \mathrm{e}$ ), and the differences between diameters were significant in the middle density stands $(\mathrm{W}=1422, P<0.01)$ and high density stands (W=1556, $P<0.01$, Fig. 3f).
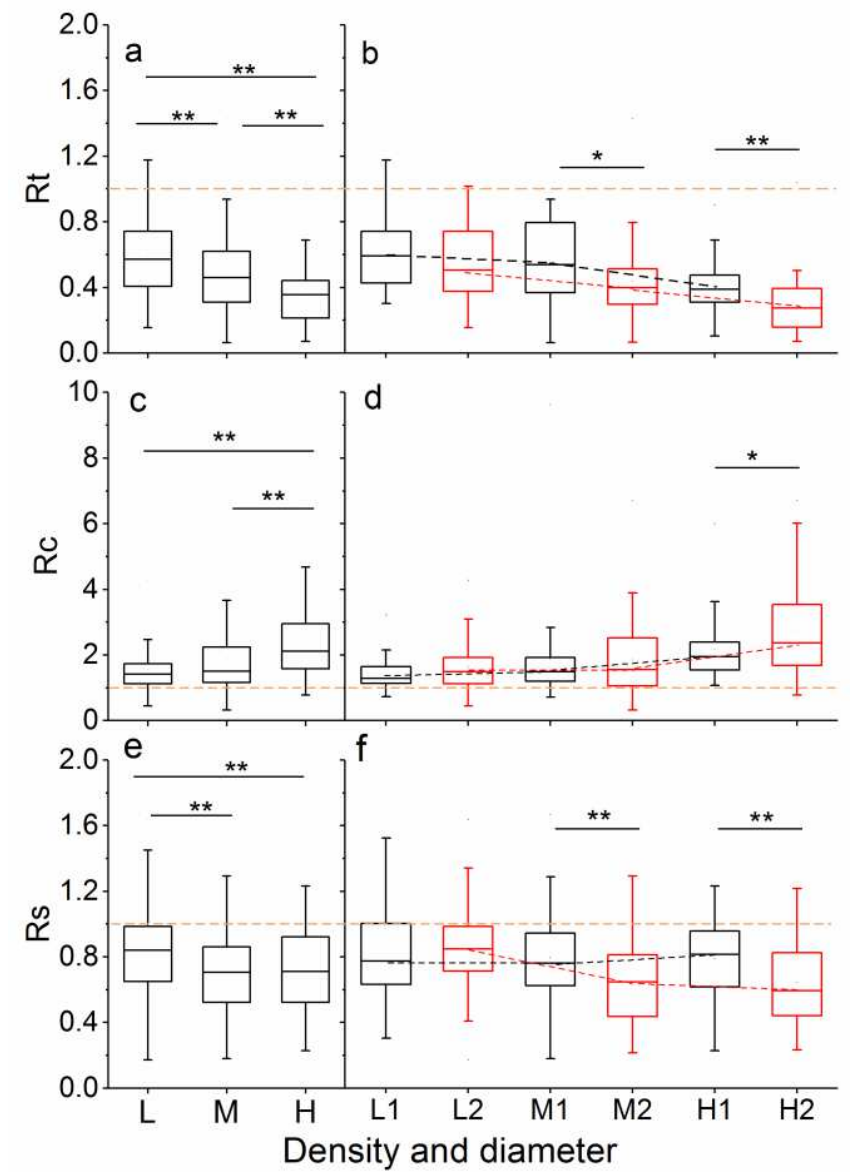

Fig. 3 Response indices among different densities and diameters. The letters L, M, and H represent low-, middle-, and high-density stands, respectively. The numbers 1 and 2 represent large- and small-diameter trees, respectively. Two asterisks indicate significant differences 
between diameters or densities $(P<0.01)$, *, significant at $P<0.05$; **, significant at $P<0.01$. The orange dash line is the value equal to one.

\subsection{Competition effect on trees' response to drought}

As density increased, the competition increased, which heightened tree sensitivity in response to drought. The results of the linear mixed models showed that the significant effect of increased SDI caused the Rt to decrease, and Rc to increase in the whole series (Table 2). The form of the model (including $\mathrm{Rt}^{\wedge} 0.5$ and $\mathrm{Rc}^{\wedge}-0.25$ ) also showed that the relationships between SDI and $\mathrm{Rt}$ or $\mathrm{Rc}$ were not linear (Fig.S1 and Fig.S3 also showed the nonlinear relationship between competition, and Rt and Rc).

It suggested that the rate of Rt decline and the rate of increase in Rc reduced with the increase of SDI.

Thus, in dense stand trees resistance to drought and recovery from drought were not sensitive to the change in competition. The Rs also decreased as the competition increased, but this relationship was not significant.

When the large- and small-diameter trees were separated, the models showed a similar pattern to that of the whole series. The marginal $\mathrm{R}^{2}$ of $\mathrm{Rt}$ and Rs was larger in small-diameter trees than those in large-diameter trees (Table 2), and compared with large-diameter trees, the response indices showed more obvious changes for small-diameter ones (Fig. 3b, c and f). This result indicated that small-diameter trees were more sensitive to the increase in competition.

Table 2 Summary of the results of the linear mixed models for the competition effect on the response to drought. The whole series refers to all series combined for the analysis. Lc indicates the large-diameter class. Sc represents the small-diameter class. The bold type means that the estimation is significant. 


\begin{tabular}{cccccc}
\hline & $\mathrm{Rt}^{\wedge} 0.5$ & $\mathbf{1 . 0 0 0 8}$ & -0.0003 & 0.1127 & 0.5498 \\
Whole series & $\mathrm{Rc}^{\wedge}-0.25$ & $\mathbf{1 . 1 0 1 9}$ & $\mathbf{- 0 . 0 0 0 2}$ & 0.1281 & 0.3629 \\
& $\mathrm{Rs}^{\wedge} 0.5$ & $\mathbf{0 . 9 2 0 0}$ & -0.0001 & 0.0054 & 0.1661 \\
& $\mathrm{Rt} \mathrm{t}^{\wedge} 0.5$ & $\mathbf{1 . 0 0 5 5}$ & -0.0003 & 0.1145 & 0.6054 \\
$\mathrm{Lc}$ & $\mathrm{Rc} \mathrm{c}^{\wedge}-0.5$ & $\mathbf{1 . 0 9 6 8}$ & $\mathbf{- 0 . 0 0 0 3}$ & 0.1185 & 0.2525 \\
& $\mathrm{Rs}$ & $\mathbf{0 . 9 0 0 7}$ & -0.0001 & 0.0061 & 0.2414 \\
& $\mathrm{Rt} \mathrm{t}^{\wedge} 0.5$ & $\mathbf{1 . 0 6 0 4}$ & -0.0004 & 0.1571 & 0.5553 \\
$\mathrm{Sc}$ & $\mathrm{Rc}^{\wedge} 0.25$ & $\mathbf{0 . 8 4 2 6}$ & 0.0003 & 0.1151 & 0.4272 \\
& $\mathrm{Rs}$ & $\mathbf{0 . 9 7 2 7}$ & -0.0002 & 0.0301 & 0.2201 \\
\hline
\end{tabular}

\subsection{Growth response to inter-annal climate variation}

328 Trees' sensitivity to interannual climate variation was weakened by increased competition. The

329 average correlation value between SPEI8 and STRWI was higher in the low-density stand than in the

330 high-density stand (Fig.4). Before 1999, MSPEI declined (Fig.2), while BAI showed upward trends for

331 all densities and diameters (Fig.5). The result showed that in their early stage their growth was not

332 sensitive to the climate fluctuations. During this stage, the increased competition caused little effect on

333 their sensitivity. Although competition became higher as trees have grown up, the MRBAI did not

334 decline. 


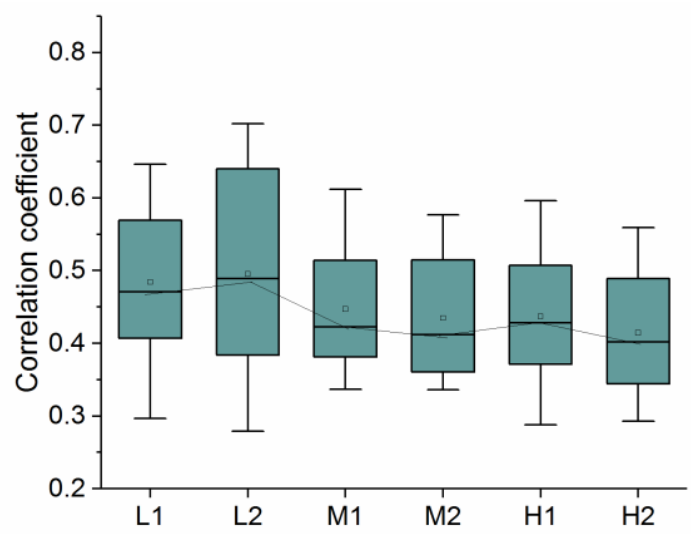

Fig. 4 Average correlation between STRWI and SPEI8 from low density. to high density.

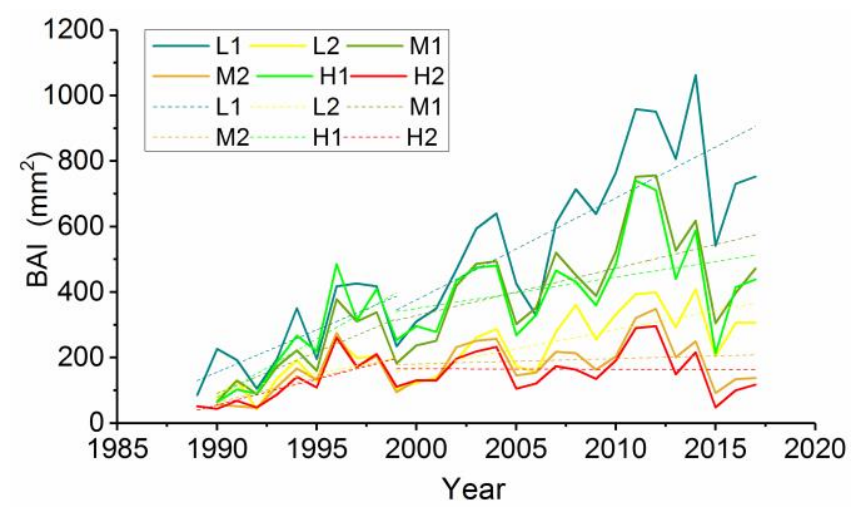

338 Fig. 5 Development of BAI. The basal area increment (BAI) is the average of each plot and diameter.

339 The letters L, M, and H represent low-, middle-, and high-density stands, respectively. The numbers 1 and 2 represent large diameters and small diameters, respectively.

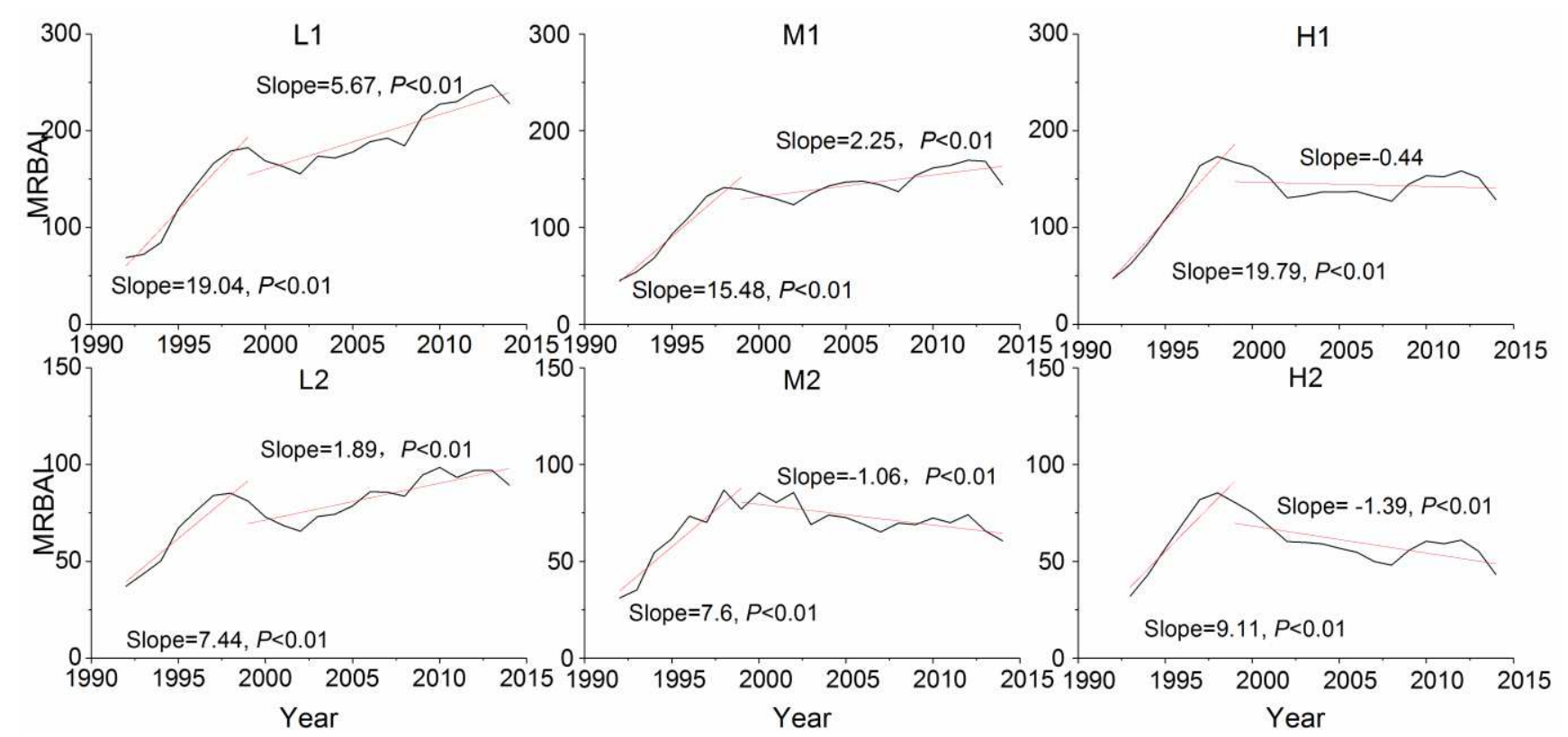

Fig. 6 Change in the MRBAI at different densities and diameters. The first period is 1990-1999. The 
second period is 1999-2017.The letters L, M, and H represent low-, middle-, and high-density stands, respectively. The numbers 1 and 2 represent large diameters and small diameters, respectively.

After 1999, although the BAI did not show a decline, the upward trends gradually plateaued for small-diameter trees in high-density stands (Fig. 5). From low to high density, the trend of the MRBAI varied from upward to downward. For large diameters, the slope decreased from 5.67 to -0.44 , while for the small diameters it decreased from 1.89 to -1.39 (Fig. 6). The result indicated that trees' sensitivity of response to climate change was reduced by the increased competition. In low-density stands, trees' sensitivity of response to long-term climate change increased, while in high-density stands it declined.

Additionally, the growth of large-diameter trees showed a higher correlation with interannual climate change. They were more sensitive to interannual climate change than small diameter trees (Fig. 4). During the whole period, when compared with large-diameter trees, small-diameter trees showed a slight increase in early stage (before 1999) and a steeper decline in the second stage (after 1999). Especially in middle- and high-density stands, small diameter tree MRBAI showed a significant decline (Fig.6), which indicates that small-diameter trees were greatly affected by increased competition. In middle- and high-density stands, small-diameter trees' response to climate change was restricted by intensive competition.

\section{Discussion}

\subsection{Competition effect on tree responses to drought}

Competition exerts impacts on tree responses to drought. Our results also showed that competition significantly increased tree sensitivity to drought. With an increase in stand density, the competition for 
water and nutrients became more intense (Vernon et al., 2018). Generally, increased competition worsens water resource shortages. We found a negative relationship between the SDI and Rt, which is consistent with the results of Gyenge et al. (2012) and Gleason et al. (2017). In addition, in our experiment, the effect of the SDI on the Rt was very weak for large-diameter trees, while the random effect had a considerable impact, which was mainly related to the weak competition from their neighbors and more favorable microenvironment. Large trees occupy a larger living space benefitting to developing their wider range of roots and larger crowns that could obtain more resources than smaller ones (Burt et al., 1985; Supplementary Information Fig. S4). In addition, their large stems could store more water for drought resistance (Phillips et al., 2003; Zang et al., 2014). Thus, they were less affected by competition.

However, some studies showed that large trees suffered greater impact and subjected to drought-induced mortality (Martínez-Vilalta et al., 2012; Bennett et al. 2015; Shenkin et al. 2018). Large trees had longer hydraulic path length and higher hydraulic resistance (Domec et al., 2008), which made them more vulnerable to hydraulic failure (Ryan et al., 2006). Besides, in their researches, the ages might differ between large- and small-diameter trees. In some cases, larger trees that suffer from weak competition are older than smaller ones that suffer from intense competition. Skubel et al. (2015) revealed that younger trees have more conservative water use strategies, while old trees showed greater variation in water use efficiency. Therefore, the effect might encompass both age and competition. Our experiment was conducted in an even-aged plantation, and the difference in height between the large- and small-diameter trees was not very obvious. Thus, the difference was mostly derived from the different growth rates and competition. Finally, in Martínez-Vilalta's research, the species, Scots pine, is sensitive to high temperature. In contrast, $P$. tabulaeformis can tolerate drought 
and high temperature (Zeng et al., 2005). Therefore, differences in species characteristics and forest structure may also lead to differences in responses to drought.

In general, the Rc is negatively related to the Rt (Gazol et al., 2017) but positively related to increasing competition. For some species, increased competition leads to the reduction of radial growth (Hui et al., 2018), but the trees have high proportions of latewood and relatively thicker cell walls. And the tree with low growth rate also has low wood density and high hydraulic conductivity, which indicate a low susceptibility of suffering from hydraulic failure (Carnwath and Nelson 2016; Rungwattana and Hietz 2018). Thus, trees growing slowly have a greater ability to recover (Bréda et al., 2006; Martin-Benito et al., 2008; Montwé et al., 2015). However, Bottero et al. (2017) showed that the Rc was negatively related to increasing densities in a ponderosa pine stand, which might be related to frequent thinning of their plots, especially for the plot with a low density (the intervals were 5-10 years). Thinning can promote the growth of residual trees, and change their physiological characteristics, which can enhance tree recovery (Thomas et al., 2014; Kiorapostolou et al. 2020), and this physiological response can last up to 15 years for mature ponderosa pines (McDowell et al. 2003). In contrast, our plots were not thinned after the trees were planted. Thus, our results could avoid the effect of competition mixed with thinning.

Although competition modified tree response to drought, the effect of competition moderately increased tree sensitivity to drought under an intensively competitive environment. Some researchers also showed that the competition effect on restricting trees' radial growth faded under intensive competition (Gómez-Aparicio et al., 2011; Sánchez-Salguero et al., 2015; Dorman et al., 2015; Gonzá lez de Andrés et al., 2017). The calculation of response indices (Rt, Rc, Rs) was based on radial growth. 
Thus, the relationship between competition and response indices was also nonlinear. In addition, previous studies showed that the effect of competition decreased with an increase in water stress (Kunstler et al., 2011; Carnwath and Nelson, 2016). In the long term, trees living in high-density stands suffer from more serious drought stress than those living in low-density stands. To adapt to low soil water content they may maintain a lower ratio of leaf area to relative sapwood (Carnwath and Nelson., 2016). This characteristic is conducive to adapting to the increased water stress induced by increased competition

However, although small-diameter trees also experienced more serious water deficits than large-diameter trees, their response index (Rt and Rs) was more sensitive to the increase in competition. The result has a great relationship with that the growth of small-diameter tree was more sensitive to the change in competition (Gómez-Aparicio et al., 2011). Generally, small-diameter trees commonly live in a less favorable microenvironment (Thomson et al., 1986; Davies et al., 2001). To some extent, the effect of competition was magnified by the difference in the micro-environment. Besides, from low density to high density, the living space of small diameter class decreased more than that of large diameter class (Supplementary Information Fig. S4). Thus, small-diameter trees were more affected by increased competition and their response was more sensitive to the increase in competition.

\subsection{Response to interannual climate change}

The results also showed that the correlation between growth and interannual climate change was influenced by competition. The competition effect on their response was not constant throughout the whole period. In the early stage competition may have been at a low level. When they were young they had a smaller LAI than when they were mature so the demand for evapotranspiration was lower. And 
the water deficit also was not very serious. So the competition effect was not evident. Besides, when they were young trees exhibited high stomatal conductance, photosynthetic rate, and high plasticity (Greenwood et al., 2008; David et al., 2018). Their speeding growth rate might cover the effect of increased competition. However, after 1999, it is obviously that the impact of competition reduced trees' sensitivity to climate change. This is consistent with previous research indicating that trees living in denser forests were not sensitive to climate change (Ford et al., 2016). In particular, the increase in competition caused trees to become insensitive to wet climate conditions (Carnwath and Nelson 2016). In crowded populations, high evapotranspiration leads to the increased moisture providing fewer benefits to individuals compared with low-density stands (Tamai et al., 2015). In high-density stands, a dense canopy and thick litter intercept some of the precipitation so that the effect of the climate becoming wetter was modulated (Motahari et al., 2013; Gerrits et al., 2010). Therefore, after 1999, although the MSPEI increased, growth at high density was less sensitive than that at low density and showed a relatively low growth rate. Reversely, Kunstler et al. (2011) reported that competition (increased density) had little impact on trees' climate sensitivity, possibly because changes in other factors moderated the impact of competition.

Compared with large-diameter trees, the small-diameter trees were greatly affected by increased density and were insensitive to interannual climate change. Some researches reported that large-diameter trees were more sensitive to climate (Martín-Benito et al. 2008; Mérian et al., 2011; Guillemot et al., 2015), while other research has shown an opposite result (Jiang et al., 2012). Previous research has demonstrated that large-diameter trees in the upper layer of a stand buffered the effect of climate variation on understory small-diameter trees (Aussenac et al., 2000). However, our experiment was conducted in single-layer stands. The buffer effect might cause little impact on the difference 
between diameters. Although it is a single-layer stand, its diameter distribution range is large (Table 1). In the even-aged stands the differences among small- and large-diameter trees were caused more by competition or other micro-environment differences. The lower sensitivity of small-diameter trees has a close relationship with the loss of plastic capacity induced by intensive competition (Linares et al., 2010). Our results also further demonstrated that small-diameter trees had a lower resilience (lower Rs of small diameter trees in middle- and high-density stands, Fig. 2) than large-diameter trees. In addition, some research showed trees with low growth rates had higher water use efficiency and more rapid stomatal regulation than large trees (Zang et al., 2012; Martínez-Sancho et al., 2017), which helps them to mitigate the effects of drought stress. Therefore, small-diameter trees growth were less sensitive to the climate becoming wetter than that of large trees.

Competition among trees increased and negatively affected trees' response ability during the process of tree growth. Tree physiology also changes at different ages during this process (David et al., 2018). Besides, in their early stage the demand for water was lower. Thus in high-density stands, the small-diameter trees did not show an obvious increasing trend in a wet period (after 1999). Moreover, as density increased, the slope of the RBAI was obviously decreased. In the future, P. tabulaeformis in high-density stands will grow slower, and in dry spells, growth may be severely reduced, especially for small-diameter trees.

Overall, trees' sensitivity to interannual fluctuations in climate was influenced by competition. In this part, the effect of competition on tree responses to climate was not constant and might be associated with the change in trees' physiologyical characteristics and other factors, such as worsened soil conditions induced by overcrowded stems (Sun et al., 2018) and demands differing in different 
471

472

473

474

475

476

477

478

479

480

481

482

stages. Further study is required to learn more about how tree physiology and competition affect tree responses to climate. Therefore, in the future, we should be paid more attention to physiological characteristics in different age classes and the combined effect of physiology and competition.

\section{Conclusion}

This study investigated the effect of competition on the response of $P$. tabulaeformis to climate. Competition increased the trees sensitivity to drought. This effect moderately increased under intense competition. Compared with large diameter trees, the small diameter trees suffering from more intensive competition were more sensitive to an increase in competition. In contrast, competition reduced trees' sensitivity to interannual climate variation. After 1999, the effect greatly affected their sensitivity, especially in middle- and high-density stands.

\section{Acknowledgments}

This research was supported by the Research and Demonstration of Difficult Site Vegetation Restoration Technology (2015BAD07B02) and the Research on Typical Fragile Ecological Restoration and Protection (2016YFC0501704). We acknowledge the staff of the Fangshan County Forestry Bureau of Luliang city, Shanxi Province, China, for their cooperation and assistance. We also thank Lushuang Gao, Qijing Liu, Yuqing Zhang, Tianshan Zha, Shuqin Liu, Xinggang Zhang, Qing Zhang and Jianping Duan for their guidance in the data analysis and other processes. In addition, we also thank the two reviewers for their valuable suggestions.

\section{References}


490

491

492

493

494

495

496

497

498

499

500

501

502

503

504

505

506

507
Aussenac G. (2000) Interactions between forest stands and microclimate: ecophysiological aspects and consequences for silviculture. Ann For Sci 57:287-301. https://doi.org/10.1051/forest:2000119

Bennett ACNG, McDowell NG, Allen CD, Anderson-Teixeira KJ. (2015) Larger trees suffer most during drought in forests worldwide. Nature Plants 1:15139.

Berger U, Hildenbrandt H, Grimm V. (2004) Age-related decline in forest production: modelling the effects of growth limitation, neighbourhood competition and self-thinning. Journal of Ecology 92:846-853. https://doi.org/10.1111/j.0022-0477.2004.00911.x

Bottero A, D'Amato AW, Palik BJ, Bradford JB, Fraver S, Battaglia MA, Asherin LA. (2017) Density-dependent vulnerability of forest ecosystems to drought. Journal of Applied Ecology 54:1605-1614. https://doi.org/10.1111/1365-2664.12847

Bréda N, Huc R, Granier A, Dreyer E. (2006) Temperate forest trees and stands under severe drought: a review of ecophysiological responses, adaptation processes and long-term consequences. Ann For Sci 63:625-644. https://doi.org/10.1051/forest:2006042

Burt TP, Butcher DP. (1985) Topographic controls of soil moisture distributions. European Journal of Soil Science 36:469-486. https://doi.org/10.1111/j.1365-2389.1985.tb00351.x

Bunn A, Korpela M, Biondi F, Campelo, Mérian P, Qeadan F, Zang C, Buras A, Cecile J, Mudelsee Schulz M. (2020) dplR: Dendrochronology Program Library in R. R package version 1.7.1. https://CRAN.R-project.org/package=dplR

Carnwath GC, Nelson CR. (2016) The effect of competition on responses to drought and interannual 
509

510

511

512

513

514

515

516

517

518

519

520

521

522

523

524

525

526

527

climate variability of a dominant conifer tree of western North America. Journal of Ecology 104:1421-1431. https://doi.org/10.1111/1365-2745.12604

Cavin L, Jump AS. (2017) Highest drought sensitivity and lowest resistance to growth suppression are found in the range core of the tree Fagus sylvatica L. not the equatorial range edge. Glob Chang Biol 23:362-379. https://doi.org/10.1111/gcb.13366

Cescatti A, Piutti E. (1998). Silvicultural alternatives, competition regime and sensitivity to climate in a European beech forest. Forest Ecology and Management 102:213-223. https://doi:10.1016/s0378-1127(97)00163-1

Chen L, Zhang Z, Ewers BE. (2012) Urban Tree species show the same hydraulic response to vapor pressure deficit across varying tree size and environmental conditions. Plos One, 2012, 7.

Colangelo M, Camarero JJ, Borghetti M, Gazol A, Gentilesca T, Ripullone F (2017) Size matters a lot: drought-affected Italian oaks are smaller and show lower growth prior to tree death. Frontiers in Plant Science 8(15139):135. https://doi.org/10.3389/fpls.2017.00135

David AAJ, Boura A, Lata JC, Rankovic A, Kraepiel Y, Charlot C, Barot S, Abbadie L, Ngao J. (2018) Street trees in Paris are sensitive to spring and autumn precipitation and recent climate changes. Urban Ecosystems 21:133-145. https://doi.org/10.1007/s11252-017-0704-z

Davies SJ. (2001) Tree mortality and growth in 11 sympatric macaranga species in borneo. Ecology $82: 920-932$.

DeLucia EH, Nabity PD, Zavala JA, and Berenbaum MR. (2012) Climate change: Resetting 

height in a conifer is associated with conflicting requirements for xylem design. Proc Natl Acad Sci characteristics to drought-induced mortality in three Southwestern pinon-juniper woodlands. HilleRisLambers J. (2016) Competition alters tree growth responses to climate at individual and individual and stand scales. Canadian Journal of Forest Research 47:53-62. https://doi.org/10.1139/cjfr-2016-0188

542 Gazol A, Camarero JJ, Vicente-Serrano SM, Sánchez-Salguero R, Gutirrez E, Luis MD,

543 Sangüesa-Barreda G, Novak K, Rozas V, Tíscar, Linares JC, Martín-Hernández N, Castillo EM, Ribas

544 M, García-González I, Silla F, Camisón A, Génova M, Olano JM, Longares LA, Hevia A, Tom 545 ás-Burguera M, Galván JD. (2017) Forest resilience to drought varies across biomes. Glob Change Biol 
547

548

549

George J-P, Schueler S, Karanitsch-Ackerl S, Mayer K, Klumpp RT, Grabner M (2015) Inter- and intra-specific variation in drought sensitivity in abies spec. and its relation to wood density and growth traits. Agricultural \& $\quad$ Forest Meteorology 214-215:430-443. https://doi.org/10.1016/j.agrformet.2015.08.268

Gerrits AMJ, Pfister L, Savenije HHG. (2010) Spatial and temporal variability of canopy and forest floor interception in a beech forest. Hydrological processes 24:3011-3025. https://doi.org/10.1002/hyp.7712

Gessler A, Cailleret M, Joseph J, Schonbeck L, Schaub M, Lehmann M, Treydte K, Rigling A, Timofeeva G, Saurer M. (2018) Drought induced tree mortality - a tree-ring isotope based conceptual model to assess mechanisms and predispositions. New phytologist 219:485-490 https://doi.org/10.1111/nph.15154

Gillerot L, Forrester DI, Bottero A, Rigling A, Lévesque M. (2020) Tree Neighbourhood Diversity Has Negligible Effects on Drought Resilience of European Beech, Silver Fir and Norway Spruce. Ecosystems (43). https://doi.org/10.1007/s10021-020-00501-y

Gleason EK, Bradford JB, Bottero A, D'amato AW, Fraver S, Palik BJ, Battaglia MA, Iverson L, Kenefic L, Kern CC. (2017) Competition amplifies drought stress in forests across broad climatic and compositional gradients. Ecosphere 8:e01849. https://doi.org/10.1002/ecs2.1849

Gómez-Aparicio L, García-Valdés R, Ruíz-Benito P, Zavala MA. (2011) Disentangling the relative importance of climate, size and competition on tree growth in Iberian forests:implications for forest management under global change. Global change biology 17:2400-2414. 
568

569

570

571

572

573

574

575

576

577

578

579

580

581

582

583

González de Andrés E, Camarero JJ, Blanco JA, Imbert JB, Lo Y-H, Sangüesa-Barreda G, Castillo FJ. (2017) Tree-to-tree competition in mixed European beech-Scots pine forests has different impacts on growth and water-use efficiency depending on site conditions. Journal of Ecology 1-17. https://doi.org/10.1111/1365-2745.12813

Greenwood MS, Ward MH, Day ME, Adams SL, Bond BJ. (2008) Age-related trends in red spruce foliar plasticity in relation to declining productivity. Tree Physiology 28:225-232. https://doi.org/10.1093/treephys/28.2.225

Guillemot J, Klein EK,Davi H, Courbet F. (2015) The effects of thinning intensity and tree size on the growth response to annual climate in Cedrus atlantica: a linear mixed modeling approach. Annals of Forest Science 72:651-663. https://doi.org/10.1007/s13595-015-0464-y

Gyenge J, Ferna'ndez ME, Varela S. (2012) Short- and long-term responses to seasonal drought in ponderosa pines growing at different plantation densities in Patagonia, South America. Trees 26:1905-1917. https://doi.org/10.1007/s00468-012-0759-7

Hannusch HJ, Rogers WE, Lodge AG, Starns HD, Tolleson DR (2020) Semi-arid savanna herbaceous production and diversity responses to interactive effects of drought, nitrogen deposition, and fire. J VEG SCI 31: 255-265

Hollander M, Wolfe DA. (1973) Nonparametric Statistical Methods. New York: John Wiley \& Sons. pp: 27-33 (one-sample), 68-75 (two-sample). 
586

587

588

589

590

591

592

593

594

595

596

597

598

599

600

601

602

603

604

Holmes, RL. (1997) The Dendrochronology Program Library, Version 2.1 users manual. The International Tree Ring Data Bank Program, Laboratory of Tree-Ring Research, University of Arizona, Tucson.

Holtmeier FK, Broll G. (2005) Sensitivity and response of northern hemisphere altitudinal and polar treelines to environmental change at landscape and local scales. Global Ecology \& Biogeography, 14:395-410. https://doi.org/10.1111/j.1466-822x.2005.00168.x

Hui GY, Wang Y, Zhang GQ, Zhao ZH, Bai C, Liu W. (2018) A novel approach for assessing the neighborhood competition in two different aged forests. Forest Ecology \& Management 422:49-58. https://doi.org/10.1016/j.foreco.2018.03.045

Jiang QB. (2012) Growth response to climate in Chinese Pine as a function of tree diameter. Beijing forestry university, thesis.

Jiao L, Chen K, Wang SJ , Liu XP. (2020) Stability evaluation of radial growth of Picea schrenkiana in different age groups in response to climate change in the eastern Tianshan Mountains. Journal of Mountain ence, 17:1735-1748. https://doi.org/10.1007/s11629-019-5703-5

Jump A, Hunt JM, Peñuelas J. (2006) Rapid climate change-related growth decline at the southern range edge of Fagus sylvatica. Global Change Biology 12: 2163-2174. https://doi.org/10.1111/j.1365-2486.2006.01250.x

Kerhoulas LP, Kane JM. (2011) Sensitivity of ring growth and carbon vary within ponderosa pine trees. Tree physiology 32:14-23. https://doi.org/10.1093/treephys/tpr112 
605

606

607

608

609

610

611

612

613

614

615

616

617

Keyser TL, Brown PM. (2016) Drought response of upland oak ( Quercus, L.) species in Appalachian hardwood forests of the southeastern USA. Annals of Forest Science 73:1-16. https://doi.org/10.1007/s13595-016-0575-0

Kiorapostolou N, Camarero JJ, Carrer M, Sterck F, Brigita B, Sangüesa-Barreda G, Petit G. (2020) Scots pine trees react to drought by increasing xylem and phloem conductivities. Tree Physiology 40:774-781. https://doi.org/10.1093/treephys/tpaa033

Kunstler G, Albert CH, Courbaud B, Lavergne S, Thuiller W, Vieilledent G, Zimmermann NE, Coomes DA. (2011) Effects of competition on tree radial-growth vary in importance but not in intensity along climatic gradients. J Ecol 99:300-312. https://doi.org/10.1111/j.1365-2745.2010.01751.x

Lingenfelder M, Newbery DM. (2009) On the detection of dynamic responses in a drought-perturbed tropical rainforest in Borneo. Plant Ecology 201:267-290. https://doi.org/10.1007/s11258-008-9568-x

Linares JC, Camarero JJ, Carreira JA. (2010) Competition modulates the adaptation capacity of forests to climatic stress: insights from recent growth decline and death in relict stands of the Mediterranean fir Abies pinsapo. J Ecol 98:592-603. https://doi.org/10.1111/j.1365-2745.2010. 01645.x

Liu M, Xu X, Sun AY. (2018) New drought index indicates that land surface changes might have enhanced drying tendencies over the Loess Plateau. Ecological Indicators 89:716-724. https://doi.org/10.1016/j.ecolind.2018.02.003

Martín-Benito D, Cherubini P, del Río MD, and Cañellas I. (2008) Growth response to climate and drought in Pinus nigra Arn. trees of different crown classes. Trees 22:363-373. 
625

626

627

628

629

630

631

63

633

634

635

636

63

638

639

640

641

642

Martínez-Sancho E, Dorado-Liñán I, Gutiérrez Merino E, Matiu M, Helle G, Heinrich I, Menzel A. (2017) Increased water-use efficiency translates into contrasting growth patterns of Scots pine and sessile oak at their southern distribution limits. Global Change Biology 24:1012-1028. https://doi.org/10.1111/gcb.13937

Martínez-Vilalta J, López BC, Loepfe L, Lloret F. (2012) Stand- and tree-level determinants of the drought response of Scots pine radial growth. Oecologia 168:877-888. https://doi.org/10.1007/s00442-011-2132-8

Mcdowell NG , Allen CD. (2015) Darcy's law predicts widespread forest mortality under climate warming. Nature Climate Change 5:669-672. https://doi.org/10.1038/NCLIMATE2641.

McDowell NG, Beerling DJ, Breshears DD, Fisher RA, Raffa KF, Stitt M. (2011) The interdependence of mechanisms underlying climate-driven vegetation mortality. Trends in Ecology \& Evolution 26:523-532. https://doi.org/10.1016/j.tree.2011.06.003

McDowell NG, Brooks JR, Fizgerald SA, Bond BJ. (2003) Carbon isotope discrimination and growth response of old Pinus ponderosa trees to stand density reductions. Plant, Cell and Environment 26: 631-644. https://doi.org/10.1046/j.1365-3040.2003.00999.x.

McDowell NG, Pockman WT, Allen CD, Breshears DD, Cobb N, Kolb T, Plant J, West A, Williams DG, Yepez EA. (2008) Mechanisms of plant survival and mortality during drought: Why do some stems survival while others succumb to drought? New Phytol 178:719-739. 
644 Merens, M. (2010) Adaptive moving average for trending of accident rates. The Aeronautical Journal

Mérian P, Lebourgeois F. (2011) Size-mediated climate-growth relationships in temperate forests: A multi-species analysis. Forest Ecology and Management 261:1382-1391.

Montwé D, Spiecker H, Hamann A. (2015) Five decades of growth in a genetic field trial of Douglas-fir reveal trade-offs between productivity and drought tolerance. Tree Genetics \& Genomes 11:29. https://doi.org/10.1007/s11295-015-0854-1 eldarica plantation in a semiarid climate cone: an application of the gash model. Journal of Agricultural ence \& Technology 15:981-994. https://doi.org/10.1684/agr.2013.0625

Paoli GD, Curran LM, Slik JWF. (2007) Soil nutrients affect spatial patterns of aboveground biomass

656 and emergent tree density in southwestern Borneo. Oecologia 155:287-299. https://doi.org/10.1007/s00442-007-0906-9 drought-induced pervasive increase in tree mortality across Canada's boreal forests. Nature Climate 
662

663

664

665

666

667

668

669

670

671

672

673

674

675

676

677

678

679

680 water increases with tree size in three species in the Pacific Northwest. Tree Physiol 23:237-245. https://doi.org/ 10.1093/treephys/23.4.237

Pinheiro, José C, Bates DM. (2000) Mixed-Effects Models in S and S-PLUS, Springer Press, New York, pp:174-197.

Pinheiro J, Heisterkamp S, Willigen BV. (2019) nlme: Linear and nonlinear mixed effects models. R package version 3.1-140._https://CRAN.R-project.org/package=nlme

Ploughe LW, Jacobs EM, Frank GS, Greenler SM, Smith MD, Dukes JS. (2019) Community response to extreme drought (CRED): a framework for drought-induced shifts in plant-plant interactions. New Phytologist 222:52-69. https://doi.org/ 10.1111/nph.15595.

Pretzsch H, Biber P. (2005) A re-evaluation of Reineke's rule and stand density index. Forest Science 51:304-320.

Qiu X, Peng D, Wang H, Wang Z, Cheng S (2019) Minimum data set for evaluation of stand density effects on soil quality in Larix principis-rupprechtii plantations in North China. ECOL INDIC 103: $236-247$.

R Core Team (2018) R: A language and environment for statistical computing. Vienna, Austria: R Foundation for Statistical Computing. https:/www.R-project.org/

Rahman M. Islam M, Gebrekirstos A, Bräuning A. (2019) Trends in tree growth and intrinsic water-use efficiency in the tropics under elevated $\mathrm{CO}_{2}$ and climate change. Trees Structure and Function 33:623-640. 
681

682

683

684

685

686

687

688

689

690

691

692

693

694

695

696

697

698

699

Reineke LH. (1933) Perfecting a stand-density index for even-aged forests. Journal of Agricultural Research 46:627-638.

Ryan MG, Phillips N, Bond BJ. (2006) The hydraulic limitation hypothesis revisited. Plant Cell Environ 29:367-381. https://doi.org/10.1111/j.1365-3040.2005.01478.x

Rubio-Cuadrado A, Camarero JJ, Río MD, Sánchez-González M, Ruiz-Peinado R, Bravo-Oviedo A,Gil

L, Montes F. (2018) Long-term impacts of drought on growth and forest dynamics in a temperate beech-oak-birch forest. Agricultural and Forest Meteorology 259:48-59. https://doi.org/10.1016/j.agrformet.2018.04.015

Rungwattana K, Hietz P. (2018) Radial variation of wood functional traits reflect size-related adaptations of tree mechanics and hydraulics. Functional Ecology 32:260-272.

Sánchez-Salguero R, Camarero JJ, Dobbertin M, Fernández-Cancio Ȧ, Vilà-Cabrera A, Manzanedo RD, Zavala MA, Navarro-Cerrillo R. (2013) Contrasting vulnerability and resilience to drought-induced decline of densely planted vs. natural rear-edge Pinus nigra forests. For Ecol Manage 310:956-967. https://doi.org/10.1016/j.foreco.2013.09.050

Sánchez-Salguero R, Linares CJ, Camarero JJ, Madrigal-González J, Hevia A, Sánchez-Miranda Á, Ballesteros-Cánovas JA, Alfaro-Sánchez R, García-Cervigón AI, Bigler C, Rigling A. (2015) Disentangling the effects of competition and climate on individual tree growth: A retrospective and dynamic approach in Scots pine. Forest Ecology and Management 358:12-25. https://doi.org/ 10.1016/j.foreco.2015.08.034 
700

701

702

703

704

705

706

707

708

709

710

711

712

713

714

715

716

717

718

Stephenson NL, Das AJ, Ampersee NJ, Bulaon BM, Yee JL. (2019) Which trees die during drought? The key role of insect host-tree selection. Journal of Ecology, 107(5). https://doi.org/10.1111/1365-2745.13176.

Beguer i a, Santiago, Sergio MV-S. 2017. SPEI: Calculation of the Standardised $\begin{array}{llllll}\text { Precipitation-Evapotranspiration } & \text { Index. } & \mathrm{R} & \text { package } & \text { version } & \text { 1.7. }\end{array}$ https://CRAN.R-project.org/package=SPEI

Schönbeck L, Li M-H, Lehmann MM, Rigling A, Schaub M, Hoch G, Kahmen A, Gessler A. (2020)

Soil nutrient availability alters tree carbon allocation dynamics during drought. Tree Physiology, tpaa139 - . https://doi.org/ 10.1093/treephys/tpaa139

Serra-Maluquer X, Mencuccini M, Martínez-Vilalta J. (2018) Changes in tree resistance, recovery and resilience across three successive extreme droughts in the northeast Iberian Peninsula. Oecologia 187:343-354. https://doi.org/10.1007/s00442-018-4118-2.

Sharma M, Parton J. (2018) Climatic Effects on Site Productivity of Red Pine Plantations. For. Sci. 00:1 - 11. https://doi.org/10.1093/forsci/fxy013

Skubel R, Arain MA, Peichl M, Brodeur JJ, Khomik M, Thorne R, Trant J, Kula M. (2015) Age effects on the water-use efficiency and water-use dynamics of temperate pine plantation forests. Hydrological Processes 29:4100-4113. https://doi.org/10.1002/hyp.10549

Sun QH, Wu X, Wang MZ, Zhang LH,Yao X L, Qi JQ, Hao JF. (2018) Effects of stand density on understory species diversity and soil physicochemical properties of Pinus massoniana plantation. 
720

721

722

723

724

725

726

727

Tamai K. (2015) Effect estimation of stem density and LAI on the evapotranspiration rate from forest stand. Journal of Ecosystems and Sustainable Development X 72(Suppl.A):195-204. https://doi.org/10.2495/ECO150181

Thomson AJ. (1986). Trend surface analysis of spatial patterns of tree size, microsite effects, and competitive stress. Canadian Journal of Forest Research, 16:279 - 282. https://doi:10.1139/x86-048

Thomas Z, Waring KM. (2014) Enhancing resiliency and restoring ecological attributes in second-growth ponderosa pine stands in northern New Mexico, USA. Forest Science 61:93-14. https://doi.org/ 10.5849/forsci.13-085.

Trujillo-Moya C, George J-P, Fluch S, Geburek T, Grabner M, Karanitsch-Ackerl S, Konrad H, Mayer K, Sehr EM, Wischnitzki E, Schueler S. (2018) Drought sensitivity of Norway Spruce at the species' warmest Fringe: quantitative and molecular analysis reveals high genetic variation among and within provenances. G3 : Genes, Genomes, Genomes 8:1225-1245. https://doi.org/10.1534/g3.117.300524

Van Gunst K J, Weisberg P J , Yang J , Fan YC. (2016) Do denser forests have greater risk of tree mortality: A remote sensing analysis of density-dependent forest mortality. Forest Ecology and Management 359:19-22. https://doi.org/10.1016/j.foreco.2015.09.032

Vernon MJ, Sherriff RL, Mantgem PV, Kane JM. (2018) Thinning, tree-growth, and resistance to multi-year drought in a mixed-conifer forest of northern California. Forest Ecology \& Management 422:190-198. https://doi.org/10.1016/j.foreco.2018.03.043 
738

739

740

741

742

743

744

745

Wang X, Zhang Y, Mcrae DJ. (2009) Spatial and age-dependent tree-ring growth responses of Larix gmelinii to climate in northeastern China. Trees 23:875-885. https://doi.org/10.1007/s00468-009-0329-9

Wilson R , Elling W. (2004) Temporal instability in tree-growth/climate response in the Lower Bavarian Forest region: implications for dendroclimatic reconstruction. Trees 18:19-28. https://doi.org/10.1007/s00468-003-0273-z

Yan MZ. (2009) The study in the individual tree growth models of natural secondary forest in Maoershan forest region. Northeast Forestry University, thesis.

Yu M, Li QF, Hayes MJ, Svoboda MD, Heim RR. (2014) Are droughts becoming more frequent or severe in China based on the Standardized Precipitation Evapotranspiration Index: 1951-2010?. International Journal of Climatology 34:545-558. https://doi.org/10.1002/joc.3701

Zang C, Pretzsch H, Rothe A. (2012) Size-dependent responses to summer drought in Scots pine, Norway spruce and common oak. Trees 26:557-569. https://doi.org/10.1007/s00468-011-0617-z

Zang C, Pretzsch H, Rothe A. (2012) Size-dependent responses to summer drought in Scots pine, Norway spruce and common oak. Trees,26(2):557-569.

Zang C, Hartl-Meier C, Dittmar C, Rothe A, Menzel A. (2014) Patterns of drought tolerance in major European temperate forest trees: climatic drivers and levels of variability. Glob Change Biol 20:3767-3779. https://doi.org/10.1111/gcb.12637 
758

759

760

761

762

763

764

765

766

767

768

769

770

771

772

773

Zeppel MJB, Anderegg WRL, Adams HD, Hudson P, Cook A, Rumman R, Eamus D, Tissue DT, Pacala SW. (2019) Embolism recovery strategies and nocturnal water loss across species influenced by biogeographic origin. Ecology and Evolution 9:5348-5361.

Zhang J, Huang SM, He FL. (2015) Half-century evidence from western Canada shows forest dynamics are primarily driven by competition followed by climate. Proceedings of the National Academy of Sciences 112: 4009-4014. https://doi.org/10.1073/pnas. 1420844112

Zhang LN, Jiang Y, Zhao SD Jiao L, Wen Y. (2018) Relationships between tree age and climate sensitivity of radial growth in different drought conditions of Qilian Mountains, northwestern China. Forests 9:135. https://doi.org/10.3390/f9030135

Zhang Y-J, Meinzer FC, Hao G-Y, Scholz FG, Bucci SJ, Takahashi FSC, Villalobos-Vega R, Giraldo JP, Cao K-F, Hoffmann WA, Goldstein G. (2009) Size-dependent mortality in a Neotropical savanna tree: the role of height-related adjustments in hydraulic architecture and carbon allocation. Plant Cell Environ 32:1456-1466. https://10.1111/j.1365-3040.2009.02012.x

Zhao PW, Xu CY, Zhou M, Zhang B, Ge P, Zheng N, Liu HY. (2018) Rapid regeneration offsets losses from warming-induced tree mortality in an aspen-dominated broad-leaved forest in northern China. Plos One 13:e0195630. https://doi.org/10.1371/journal.pone.0195630

Zhou ZC, Shangguan ZP. (2007) Vertical distribution of fine roots in relation to soil factors in Pinus tabulaeformis Carr. forest of the Loess Plateau of China. Plant and Soil 291:119-129. 


\section{Supplementary Files}

This is a list of supplementary files associated with this preprint. Click to download.

- supplymentaryinformatiion.doc

- DataTreeringwidth.xls

- DataTreelocationinplot.xls 